\title{
The Effect of Culture on Food Consumption; a Case of Special Religious Days in Turkey
}

\author{
Dilistan Shipman ${ }^{1} \&$ Beril Durmus ${ }^{2}$ \\ ${ }^{1}$ Istanbul Bilgi University, Turkey \\ ${ }^{2}$ Faculty of Business Administration department of Quantitative Techniques, Marmara University, Turkey \\ Correspondence: Dilistan Shipman, Istanbul Bilgi University, Turkey. E-mail: dilistan.shipman@ bilgi.edu.tr
}

Received: October 19, 2016

Accepted: March 1, 2017 Online Published: March 27, 2017

doi:10.5539/jfr.v6n2p92

URL: https://doi.org/10.5539/jfr.v6n2p92

\begin{abstract}
Cultural beliefs and traditions influence the consumption and the preparation of certain foods especially in special times in different cultures. Religion and traditions in different cultures lead to restrictions of some food from the diet. Culture and religion influence food consumption patterns. This paper documents how culture, religion and traditional knowledge impacts the food purchasing behavior and food choices. Most people in Turkey are Muslims and traditionally, their food consumption is influenced by the culture especially in Ramadan which involves religious fasting days and Ramadan is a time to purify the soul, refocus attention on God, and practice self-discipline and sacrifice. "Şeker Bayramı" which symbolizes the end of the fasting, is the first day of Shawwal, and it is the 10th month of the Islamic calendar period in which people treat their guests to sweets and traditional desserts. "Kurban Bayramı" commemorates Ibrahim's willingness to sacrifice his son Ishmael to show his faithfulness to Allah takes place 70 days after the end of Ramadan and during these days the meat of the slaughtered animal is shared with the poor and neighbors. The purpose of this paper is to investigate the role of Islamic beliefs and culture in moderating consumer's attitudes, purchase intentions and consumption of food during these special days. A questionnaire was administered online among 297 participants and the responses were collated with factor analysis, independent sample T-test and ANOVA tests. The empirical research indicates variable food consumption practices during the Muslim festivals.
\end{abstract}

Keywords: culture, food consumption, religious Days

\section{Introduction}

The hasty worldwide changes in food supplies and food consumption behaviour are caused by both globalization and modernization over the last 50-60 years the development and marketing of Western-style fast foods have been one of the major changes we can see in the food market.

Although food consumption is mainly considered as an intake of nourishment in order to survive, it is also accepted as collecting information about the backgrounds, history and culture of different countries and developing social practices in which people relating other people in social, cultural and political terms (Oosterveer, 2006). All human beings eat to survive but they also eat and share food to express gratitude and thankfulness, for a sense of belonging, as part of family and cultural traditions, and for self-realization. The meal times and components of a meal vary across cultures.

Culture, religion and traditional knowledge affect food, food consumption and food preferences. Certain beliefs and practices have an impact and also characterize practices of food (Alonso, 2014) especially on certain and significant events such as holy days for Muslims.

According to Swidler (2003) culture consisting of diverse things in which how one may think, feel, or do and this shows us how one brings the task of understanding and managing everyday situations. Moreover, being one of the components of culture, food cultures or foodways reveal how a certain group of people express, create, maintain, and reinforce their (sub) cultural, ethnic, and individual identities through symbolic expressions (Penaloza, 1994 and Reilly and Wallendorf, 1987). According to Earls (1993) food cultures or foodways are given to individuals through cultural heritage. Food culture tells important historical events, legends, folklore and traditions (Mitchell, 2009, Mintz, 1996, Sanjur, 1995). Consuming traditional foods symbolically connects and maintains an ethnic identity (Hughes, 1997) like eating dates or having them on the table on Ramadan 
months, as dates were Prophet Mohammed's (peace be upon him) food on the table on Ramadan months.

Between foodways and cultural identity there is a mutual relationship. As communities shape cultural identity, cultural identity also shapes food culture- foodways. Consequently, it can be said that the demand for certain foods and the meaning attached to specific foods, the styles of preparation and serving, and eating practices are shaped by food culture.

Religion also shapes the food culture- foodways in a community like the culture. However, culture is dynamic and according to Fieldhouse (1995) it is adapting to altered circumstances and integrating new information. Compared to culture, a proper definition of religion proposes a relationship between humanity and the supernatural or a higher order of existence, beliefs in unobservable beings and notions of sacredness (Dow 2007; Stark 2004). "The concept of religion is like the concept of culture. It is easy to use in ordinary discourse, but difficult to define precisely" (Dow 2007:4). Therefore, the effect of religion on food culture, demand of foods is more rigid compared to culture, as it is not changeable. In some religions food restrictions affect the consumption of food, eating times and what to eat in certain times. In this research, the impact of special days on the consumption of food will be investigated.

\section{Relationship between Culture, Religion, and Food}

Beliefs, values, and attitudes which are practiced and acknowledged by the members of a group or a community, defines the concept of culture. "Culture means the whole complex of traditional behaviour which has been developed by the human race and is successively learned by each generation" (Muller, 2005).

Culture is a learned concept it is not inherited and it is linked with the social structure and in this sense, the individuals of a community are the carriers of culture (Muller, 2005). As culture is learned, it can be said that the information is spread orally from generation to generation and it can be seen and observed and practiced in the form of stories, cultural values, rituals and beliefs (Muller, 2005).

Taking all these into consideration, it is possible to say that food can be considered as one of the most easily reached point of entry into a community (Monin and Szczurek, 2014) to understand and evaluate cultures, subcultures and traditions as food is universal but different cultural groups and different societies have different choices of food due to religion, beliefs and ethnic behaviours. "Eating is a daily reaffirmation of [one's] cultural identity" (Kittler, et al, 2012). Therefore, it can be stated that the food choices, food culture and food consumption habits can reveal an insight of a culture.

How does culture influence food preferences? According to Rozin (2007) food preferences are mostly mediated by exposure. As Zajonc (1968) said, between exposure and liking, most of the time there is a positive relationship and the main factor of the exposed foods depends on the culture. Most people associate some foods with family, memories of special days and these can also be considered as comfort foods in case of stress and depression. According to a research flavour conditioning (Eertmans et al., 2001) also plays an important role in food choices. This flavour conditioning can be influenced by direct or indirect social factors (de Castro and Brewer, 1992) and family food rules in childhood (De Bourdeaudhuij, 1997). For example, some food put on the table by the mother on special days and shared communally can influence food preferences. Thus it can be stated that through family food culture and traditions (e.g. Ramadan, Şeker Bayramı and Kurban Bayramı) are transferred to the next generations (Monin and Szczurek, 2014).

In almost every culture some foods symbolize and are related with certain days, traditions and sharing of food is the main construct of social connections, ties and values. This can be seen mostly in the case of traditional meals on celebrations and some religious holiday meals where people interact with rituals (Rozin, 1996).

Religion also has an important impact on culture, food choices, and lifestyle and food consumption patterns (Heiman, et al., 2001). In case of food preferences, violating religious edicts (e.g., pork for Muslims), food taboos and respect for tradition determines the food choices of the communities (Monin and Szczurek, 2014).

This research emphasizes what foods are eaten due to culture and religion and their impact on food choices on special times of Islam religion.

\subsection{Islam Religion: Its Special Days and Food}

The daily lives of members in any cultural group and one's moral system and the ethics of a society are shaped by religion. Therefore the purchase behaviour is also based on the religion if they are devoted to their religion (Mokhlis \& Spartks, 2007). In the context of food, foods in Islam religion are categorised as "Haram" (foods that should be avoided) and "Halal" (foods than may be eaten) which are also applied to the other parts of life, too. Helal which is derived from Halla means legal, legitimate and allowed for Muslims (Jallad, 2008) and this 
concept plays a key role in a Muslim's life in order to buy and consume permissible foods (Rajagopal, et al., 2011).The list of haram foods includes pork, alcohol, the flesh of carrion (dead animals), blood in any form, and any products that may contain traces of these ingredients (Hussaini, 1993). The three holy days of Islam Ramadan, "Şeker Bayramı" and "Kurban Bayramı" and the foods which are eaten in these special times are involved in this research.

"O you who believe' Fasting is prescribed to you as it was prescribed to those before you that you may (learn) self-restraint." Al-Qur'an, 2:183

Holy month Ramadan which is the 9th month of the lunar (354 days) takes place 11 days earlier every year, and may happen in any of the four seasons. It is said that one can see one season only once in life. In Ramadan, Muslims fast and refrain from eating, drinking, smoking, and having sexual relations from dawn to sunset. During this time, which is 29-30 days based on the exposure of the crescent moon, food choices go through major differences (Gharbi et al., 2003). Being the fourth pillar of Islam, every healthy Muslim since he experiences puberty should fast. However, Muslim adults who are ill, travelling (distance dictated by Islamic rules), pregnant, diabetic (according to doctor's advice) or going through menstrual bleeding are not allowed to fast. The fasting time depends on the season and on the geographical location and it can be as long as 18-h a day in the summer of temperate regions or even longer. The eating times change as well as the food choices during Ramadan. Each day before dawn a meal called "sahour" is eaten and the fast-breaking meal is known as "iftar" (Ramadan et al., 1999). The food choices differ in this month and traditional meals (e.g. dates which was the most commonly consumed food by Prophet Mohammed, bread called "Pide" and olives) are prepared and food is shared with others.

"Şeker Bayramı" also called "Ramadan Bayram” (Id Al-Fitr or Eid al-Fitr) starts just after Ramadan ends. These holy days were called "iyd-i fitr" meaning ending of the fourth pillar - the Islamic duty. In Turkish people saiy "şükür" meaning gratitude, but with the time "şükür" turned into "şeker" meaning sweets and sugar due to mispronunciation. People are grateful that they could fast and show their gratitude by celebrating. In these 3 days if people resolve their misunderstandings, visit the elderly and visit the deceased one's graves and pray for them (Bardakç1, 2015). Young ones get presents from the elderly and food is shared with others. End of Ramadan people are so grateful that they could fast and complete their duties that they give food to the poor ones. A tradition in Ottoman times was to give food which is consisting of mutton and some fruit cooked together -Zirva- to the poor in the alms-houses near the mosques. It is also a tradition to give "Baklava" and "Börek" to the guests. It is said that serving sweets tradition in these holly days comes from Prophet Mohammed. To serve almond paste candies and sugar candy "Akide şekeri" is the tradition of these days. (Bozkurt, 1992).

\section{"It is not their meat nor their blood that reaches Allah; it is your devotion that reaches Him" Qur'an 22:37}

"Kurban Bayramı" (Id Al-Adha or Eid al-Adha) is another religious time which lasts for 4 days. It takes place about 70 days after Ramadan and at the end of the Hajj (annual pilgrimage to Makkah). According to old belief it is unlucky to get married or start a new business in the period between these two holidays. "Kurban Bayramı" (English: Sacrifice Feast) honours the story about Prophet İbrahim (Abraham) who showed obedience to God by agreeing to sacrifice his son. God appeared in a dream to Prophet Ibrahim and told him to sacrifice his son Ismail. Although the devil attempted to persuade Ibrahim to disobey Allah and not to sacrifice his son, Ibrahim and Ismail set off to Mina for the sacrifice. However, as Ibrahim prepared to kill his son Allah stopped him and gave him a sheep to sacrifice instead. Muslims who can afford to, sacrifice domestic animals, usually sheep, as a symbol of Ibrahim's sacrifice. The meat is shared among family, friends, neighbours and the poor, who each get a third share. After coming from "Namaz" which is the Muslim payer in mosques, traditionally the first food eaten on those days is "Kavurma" which is a type of meat dish from the scarified animal (Bayraktar, 1992).

\section{Research Method}

\subsection{Instrument}

The aim of this study was to explore food preferences due to culture and religion and their impact on food choices on special times of Islam religion. The questionnaire consisted of 3 sections. First section covered the frequency of specific foods consumption in "Ramadan Bayram" (Şeker Bayramı), "Kurban Bayramı" and Ramadan. Second section covered the food consumption behaviour in "Ramadan Bayram" (SSeker Bayramı) and "Kurban Bayramı". The last section covered the demographic data of the respondents. This questionnaire was developed based on literature data

Respondents rated the items on a 5-point scale ( $1=$ strongly disagree, $5=$ strongly agree).The second part of the questionnaire included questions regarding gender, age, annual income and education level. 


\subsection{Sampling and Data Collection}

Data for this study were collected from Turkish people who are living in Istanbul. Participation in the study was completely voluntary. Data for this research was collected through online questionnaire. All respondents are Muslim. 250 questionnaires were distributed and sample of 206 were used. Data obtained from questionnaires was analysed through the IBM SPSS statistical packet program.

Table 1. Descriptive Information of Sample

\begin{tabular}{clrr}
\hline \multirow{5}{*}{ Gender } & & Frequency & Percent \\
\cline { 2 - 4 } & Female & 126 & 61.2 \\
& Male & 80 & 38.8 \\
& Total & 206 & 100 \\
\hline \multirow{5}{*}{ Education Level } & Secondary School & 1 & 0.5 \\
& High School & 7 & 3.4 \\
& University & 137 & 66.5 \\
& Master & 39 & 18.9 \\
& PhD & 22 & 10.7 \\
& Total & 206 & 100 \\
\hline \multirow{5}{*}{ Income Level } & up tol000 TL & 23 & 11.2 \\
& $1001-2000 T L$ & 11 & 5.3 \\
& $2001-3000 T L$ & 30 & 14.6 \\
& 3001 - 4000 TL & 21 & 10.2 \\
& $4001-5000$ & 32 & 15.5 \\
& 5001 and more & 89 & 43.2 \\
& Total & 206 & 100 \\
\hline \multirow{3}{*}{ Marital Status } & Single & 108 & 47.6 \\
& Married & 98 & 52.4 \\
& Total & 206 & 100 \\
\hline
\end{tabular}

A total of $126(61.2 \%)$ of the participant were female and $80(38.8 \%)$ of the participant were male. The majority of the respondents (43.2\%) has an income level between $5001 \mathrm{TL}$ and more TL. 11.2\% of them have an income level below $1000 \mathrm{TL}, 14.6 \%$ of them have an income level between 2001-3000 TL, 10.2\% of them have an income level between 3001-4000 and 15.5\% of them have an income level of 4001-5000 TL. Among 206 respondents $66.5 \%$ of them are university graduates. The average age was 37.48 year with a 12.97 standard deviation), ranging from 18 to 70 years.

\subsection{Analyses}

\subsubsection{Descriptive Analysis}

To get more insight about Turkish consumers food consumption during special days, we found mean scores of food type separately. Soup, Pide, Pasta, Yoghurt, Cheese, Dates, Salad, Fruit, Güllaç, Cream, Honey, Jam, Olives, Water, Milk, Ayran, Fruit Compote, Nuts, Almonds, Meat dished, Vegetable meals, Simit consumed mostly in Ramadan. 
Table 2. Mean scores of food consumption frequency

\begin{tabular}{llllllll}
\hline Food & Ramadan & Şeker Bayrami & Kurban Bayramı & Food & Ramadan & Şeker Bayrami & Kurban Bayramı \\
\hline Soup & 4.04 & 3.15 & 3.47 & Water & 4.88 & 4.83 & 4.84 \\
Pide & 4.05 & 2.35 & 2.31 & Milk & 2.46 & 2.45 & 2.38 \\
Rice & 3.29 & 3.30 & 3.58 & Tea & 4.25 & 4.33 & 4.28 \\
Pasta & 2.75 & 2.56 & 2.49 & Coffee & 3.80 & 4.08 & 4.01 \\
Yoghurt & 4.05 & 3.64 & 3.70 & Soft Drinks & 2.79 & 2.79 & 2.89 \\
Cheese & 4.20 & 3.74 & 3.68 & Ayran & 3.34 & 3.21 & 3.32 \\
Dates & 3.43 & 1.82 & 1.70 & Fruit Compote & 2.86 & 2.40 & 2.46 \\
Sucuk & 2.69 & 2.91 & 2.95 & Nuts & 2.91 & 2.86 & 2.86 \\
Salad & 3.84 & 3.77 & 3.76 & Almonds & 3.00 & 2.92 & 2.88 \\
Fruit & 3.71 & 3.68 & 3.59 & Meat dishes & 4.07 & 3.98 & 4.25 \\
Icecream & 2.82 & 2.99 & 2.83 & Vegetable meals & 3.73 & 3.49 & 3.34 \\
Güllaç & 2.95 & 1.57 & 1.41 & Hamburger & 2.00 & 2.09 & 2.09 \\
Baklava & 2.80 & 3.32 & 3.28 & Döner & 2.57 & 2.67 & 2.59 \\
Cream & 2.81 & 2.73 & 2.64 & Simit & 3.02 & 2.88 & 2.83 \\
Honey & 3.15 & 2.73 & 2.57 & Lahmacun & 2.44 & 2.54 & 2.46 \\
Jam & 2.92 & 2.50 & 2.45 & Turkish Delight & 2.03 & 3.03 & 2.86 \\
Olives & 4.01 & 3.37 & 3.32 & Chocolate & 2.87 & 3.82 & 3.64 \\
Börek & 3.15 & 3.43 & 3.38 & Sugar/Candy & 2.78 & 3.22 & 2.96 \\
\hline
\end{tabular}

Consumption of specific foods were found to be different for special religious days.

\section{Food Consumption}

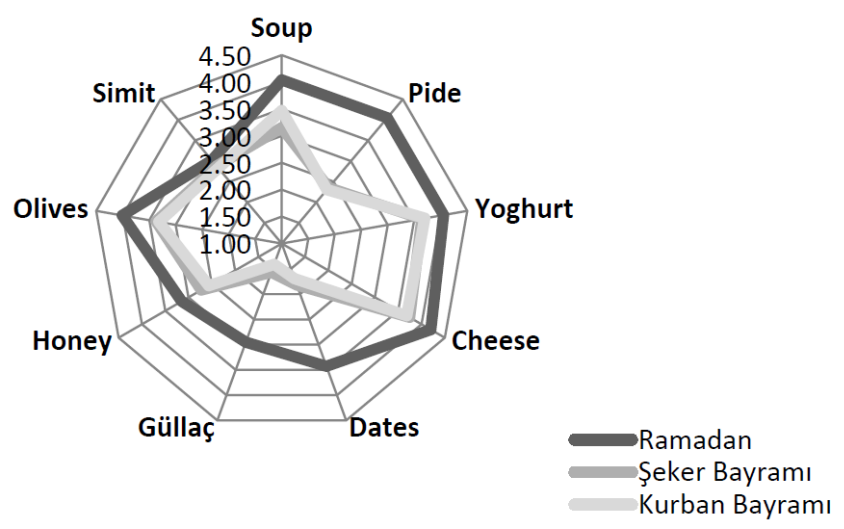

Figure 1. Food consumption mean scores

In Table 3 the means and standard deviations relating to Ramadan are given. When the values are carefully examined, it is salient to see that the average of the means of the responses are over 3.00 in Ramadan. In addition, the responses to the questions regarding "food consumption", there are desserts that they mostly answered as "quite agree". 


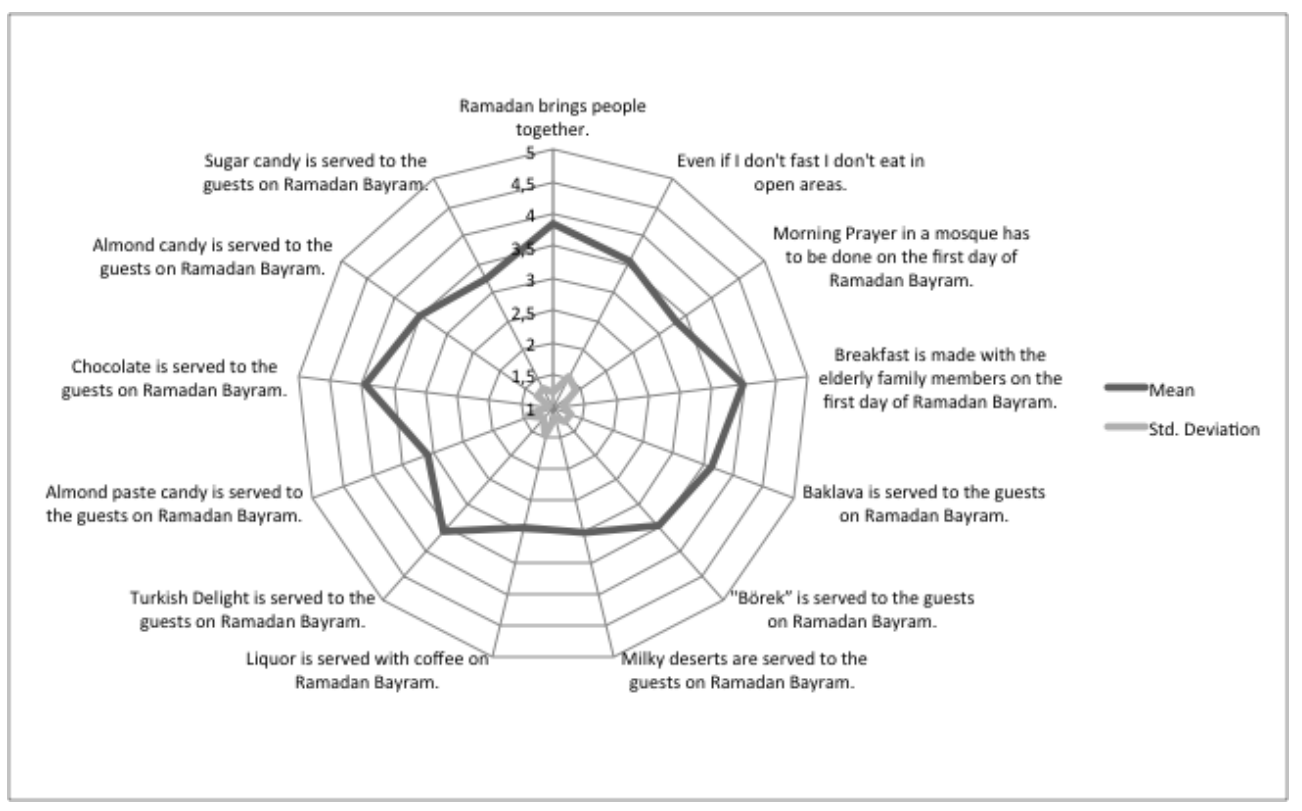

Figure 2. Mean and standard deviation scores of food consumption during Şeker Bayramı

The most striking response regarding the questions about "Kurban Bayramı" is that Tukish people give and share the slaughtered animal's meat with the ones who are in need (The meat of the sacrificed animal has to be given to the people in need, 4.55). Moreover, in "Kurban Bayramı" they do not prefer to buy meat from a butcher/supermarket and mostly consume "Kavurma" ("Kavurma" has to be on the table as a meal on Kurban Bayram1, 3.59). See Table 3.

Table 3. Mean scores of food consumption during Kurban Bayramı

\begin{tabular}{llll}
\hline Item & N & Mean & Std. Deviation \\
\hline Morning Prayer in a mosque has to be done on the first day of Kurban Bayramı. & 198 & 3.28 & 1.48 \\
An animal has to be ritually sacrified to Allah on Kurban Bayramı. & 199 & 2.97 & 1.36 \\
The meat of the sacrificed animal has to be given to the people in need. & 200 & 4.55 & 0.88 \\
"Kavurma" has to be on the table as a meal on Kurban Bayramı. & 199 & 3.59 & 1.46 \\
I don't buy meat from a supermarket/butcher in "Kurban Bayramı" & 200 & 3.00 & 1.60 \\
\hline
\end{tabular}

\section{Conclusion and Discussion}

This paper offers a perspective of people's consumption frequency of specific foods and their consumption behaviour towards them during special religious days in Turkey. For virtually all item pairs tested, food preferences and reported frequencies of consumption of the same foods were significantly correlated with each other. This descriptive analysis shows that traditional food items like dates, olives, "pide" which is a traditional bread in Ramadan, "güllaç" which is a typical milky dessert, cream and honey, jam, yoghurt, cheese and as beverages water, tea and yoghurt drink "ayran" are consumed more frequently in Ramadan with mean scores of between 3.43-4.88 (Table 2). All these foods consumed during Ramadan has reasons both from culture and religion. Prophet Mohammed on his "iftar" table (end of fasting) had dates and olives with a glass of water and at the end tea was drunk. As the Turkish people gathered in Anatolia "iftar" table has become varied with the typical Anatolian foods like "kaymak" (some sort of cream), yoghurt, cheese and "pide" as bread. "Simit" which is basically dough with sesame seeds on it, is a street food and also consumed more frequently (mean score 3.02) in Ramadan shows us that it is substituted for "pide" mostly in Ramadan meal times most probably when people had to finish their fasting time on the road home.

Ramadan Bayram or "Şeker Bayramı" meaning sugar bayram is the time when sweet food products are consumed the most. However, "güllaç" which is a traditional Ramadan dairy dessert is not consumed as a dessert in Ramadan bayram indicates that "güllaç" is considered as a dessert consumed in only Ramadan. On the other hand, "Baklava" phyllo pastry filled with different nuts are consumed (Table 2) and served (Table 3). "Baklava" is considered as a traditional dessert by Turkish people. "Börek" (Table 2 and 3) which is a handmade dough 
layers also consumed a lot in Ramadan Bayram because it is also consired as a traditional dish by Turkish people. Turkish Delight, Almond Paste and sugar candy "Akide şekeri” are consumed more frequently in Ramadan Bayram than other religious days as Ramadan Bayram is mostly associated with sweets and these sweets are very traditional Turkish sweets since the Ottoman times.

In "Kurban Bayramı" which symbolizes slaughtering an animal to honour Prophet İbrahim, meat dishes are consumed the most and rice as a garnish is consumed more compared to the other times (Table 2) as rice in Turkish cuisine is considered the best garnish for meat dishes. A traditional meat meal called "Kavurma" with a mean of 3,59 consumed in "Kurban Bayramı" reveals that Turkish people enjoy traditional foods in these special religious days. Kavurma is only made in "Kurban Bayramı" from the meat of the slaughtered animal. Sweet food products are also served and consumed in "Kurban Bayramı" but chocolate is more consumed compared to "Turkish Delight" and sugar candy. This can also be interpreted as chocolate is a better combination to meat dishes than Turkish delight.

Food is an important part of human relations in a culture and it is used to express social relations in different ways (Colt, 2006). This study shows that culture has an impact on people's food consumption attitude on these special religious days.The questions "Even if I don't fast I don't eat in open areas" with a mean of 3.55, "Breakfast is made with the elderly family members on the first day of Ramadan Bayram" with a mean of 3.98 reveals that Turkish people are influenced by the culture and "The meat of the sacrificed animal has to be given to the people in need" - Koran, Al-Hajj-28, Surah 22 - with a mean of 4.55 show us that Turkish people are influenced by religion. As this survey is done mostly among educated sample, it should also be done among less educated respondents in order to get more generalized conclusions. This study and a further study with less educated respondents can give a detailed insight to the food producers and marketers especially on these special days.

\section{References}

Assadi, M., Akrami, A., Beikzadeh, F., Seyedabadi, M., Nabipour, I., \& Larijani, B. (2011). Impact of Ramadan fasting on intraocular pressure, visual acuity and refractive errors, Singapore Med Journal, 52, 263-6.

Azizi, F. (2002). Research in Islamic fasting and health. Ann Saudi Med., 22, 186-91.

Bardakçı, M. (2015). http://www.haberturk.com/yazarlar/murat-bardakci/1104057-seker-bayrami-daha-dogrusu-sukur-bayrami . Accessed on 21.09.2016

Bayraktar, İ. (1992). Islam Encyclopaedia. İslâmî dönem/Bayram Kutlamaları, 5, 259.Accessed:22.08.2016 http://www.islamansiklopedisi.info/dia/ayrmetin.php?idno=050259\&idno2=c050177\#1

Bozkurt, N. (1992). Islam Encyclopaedia. İslâmî dönem/Bayram Kutlamaları). cilt: 5, 261-263. Access: 20.08.2016 http://www.islamansiklopedisi.info/dia/ayrmetin.php?idno=050259\&idno2=c050177\#1

Brumann, C. (1999). Writing for culture: Why a successful concept should not be discarded [and comments and reply]. Current Anthropology 40. https://doi.org/10.1086/200058

Coff, C. (2006). The Taste for Ethics. An Ethic of Food Consumption. Springer. NY. USA. Accessed30.08.2016 https://www.researchgate.net/profile/Christian_Coff/publication/230750594_The_Taste_for_Ethics_An_Eth ics_of_Food_Consumption/links/555daaa108ae86c06b5db4f2.pdf

De Bourdeaudhuij, I. (1997). Perceived family members' influence on introducing healthy food into family. Health Education Research, 12, 77-90. https://doi.org/10.1093/her/12.1.77

De Castro, J. M. (1991). Social facilitation of the spontaneous meal size of humans occurs on both weekdays and weekends. Physiology and Behavior, 49, 1289-1291. https://doi.org/10.1016/0031-9384(91)90365-U

Dow, James, W. (2007). A Scientific Definition of Religion. Anpere: Anthropological Perspectives on Religion. http://www.anpere.net/2007/2.pdf.

Eertmans, A., Baeyens, F., \& Van den Bergh, O. (2001). Food likes and their relative importance in human eating behavior: review and preliminary suggestions for health promotion. Health Education Research: Theory and Practice, 16(4), 443-456. https://doi.org/10.1093/her/16.4.443

Fieldhouse, Paul. (1995). Food and Nutrition: Customs and Culture. Ed. 2. Chapman \& Hall Ltd. https://doi.org/10.1007/978-1-4899-3256-3

Gharbi, M., Akrout, M., \& Zouari, B. (2003). Food intake during and outside Ramadan. East. Mediterr. Health J. $9(1-2), 131-140$ 
Hakku, F., Tazi, A., \& Iraki, L. (1994). Ramadan, health and chronobiology. Chronobiol. Int., 11, 340-342. https://doi.org/10.3109/07420529409057250

Heiman, A., Just, D. R., McWilliams, B., \& Zilberman, D. (2001). Incorporating Family Interactions and Socioeconomic Variables into Family Production Functions-The Case of Demand for Meats. Agribusiness: An International Journal, 17(4), 455-468. https://doi.org/10.1002/agr.1029

Hughes, M. (1997). Soul, black women, and food. C. Counihan, P. Van Esterick (Eds.). Food and Culture. Routledge, New York. pp. 272-280.

Hussaini, M. M. (1993). Islamic dietary concepts and practices. Bedford Park (IL): Islamic Food and Nutrition Council of America.

Jallad, N. A. (2008). The concepts of al-halal and al-haram in the Arab-Muslim culture: a translational and lexicographical study. Language Design, 10, 77-86.

Kittler, P. G., Sucher, K. P., \& Nelms, M. N. (2012). Food and culture (6th ed.). Belmont, CA: Wadsworth.

Mokhlis, S., \& Spartks, L. (2007). Consumer Religiosity and Shopping Behaviour in Kuala Lumpur. Malaysian Management Journal, 11(1 \& 2), 87-101.

Monin, B., \& Szczurek, L. M. (2014). Food and culture. In Adam B. Cohen's (Ed.) Culture reexamined: Broadening our understanding of social and evolutionary influences, pp. 155-190. Washington, DC: American Psychological Association. https://doi.org/10.1037/14274-009

Muller, A. (2005). Concepts of Culture: Art, Polics and Society, University of Calgary Press. Alberta,Canada. pp. 50.

Oosterveer, P. (2006). Globalization and sustainable consumption of shrimp: consumers and governance in the global space of flows, International Journal of Consumer Studies, 30(5), 465-476. https://doi.org/10.1111/j.1470-6431.2006.00535.x

Rahman, M. M., Rashid, S., Basher, S. Sultana, \& Nomani, M. Z. A. (2004). Improved serum HDL cholesterol profile among Bangladeshi male students during Ramadan fasting, East. Mediter. Health. J., 10, 131- 137.

Rajagopal, S., Ramanan, S., Visvanathan, R., \& Satapathy, S. (2011). Halal certification: implication for marketers in UAE, Journal of Islamic Marketing, 2(2), 138-153. https://doi.org/10.1108/17590831111139857

Ramadan, J., Telahoun, G., Al-zaid, N., \& Barac-nieto, M. (1999). Responses to exercise, fluid and energy balances during Ramadan in sedentary and active males, Nutr., 15, 735-739.

https://doi.org/10.1016/S0899-9007(99)00145-8

Rozin, P. (2007). Food and eating. Handbook of cultural psychology, 391-416.

Sakr, A. H. (1975). Fasting in Islam. J. Am. Diet. Assoc., 67, 17-21.

Stark, Rodney. (2004). Exploring the Religious Life. JHU Press.

Swidler, A. (2003). Talk of love: how culture matters, University of Chicago Press, Chicago, IL.

Zajonic, R. B. (1968). Attidudinal effects of mere exposure, Journal of Personality and Social Psychology, 9 , 1-27. https://doi.org/10.1037/h0025848

\section{Copyrights}

Copyright for this article is retained by the author(s), with first publication rights granted to the journal.

This is an open-access article distributed under the terms and conditions of the Creative Commons Attribution license (http://creativecommons.org/licenses/by/4.0/). 